\title{
Second and Third Oxygen Converter Plants in U. S. Under Construction
}

Following the successful operation of three 50-ton oxygen lance converters at McLouth Steel Corp. at Trenton, Mich., an oxygen converter plant of 300,000 ton capacity is being constructed at Jones \& Laughlin Steel Corp.'s Aliquippa, Pa. plant and is expected to be in operation early in 1957. Kaiser Engineers, the U.S. Licensor of the process, is also installing two 65ton oxygen converters at Kaiser Steel Corp.'s Fontana, Calif. plant. Construction will get underway at once, and the plant is scheduled for operation in 1958, raising the production of finished steel products by some half million tons.

\section{L-D PROCESS}

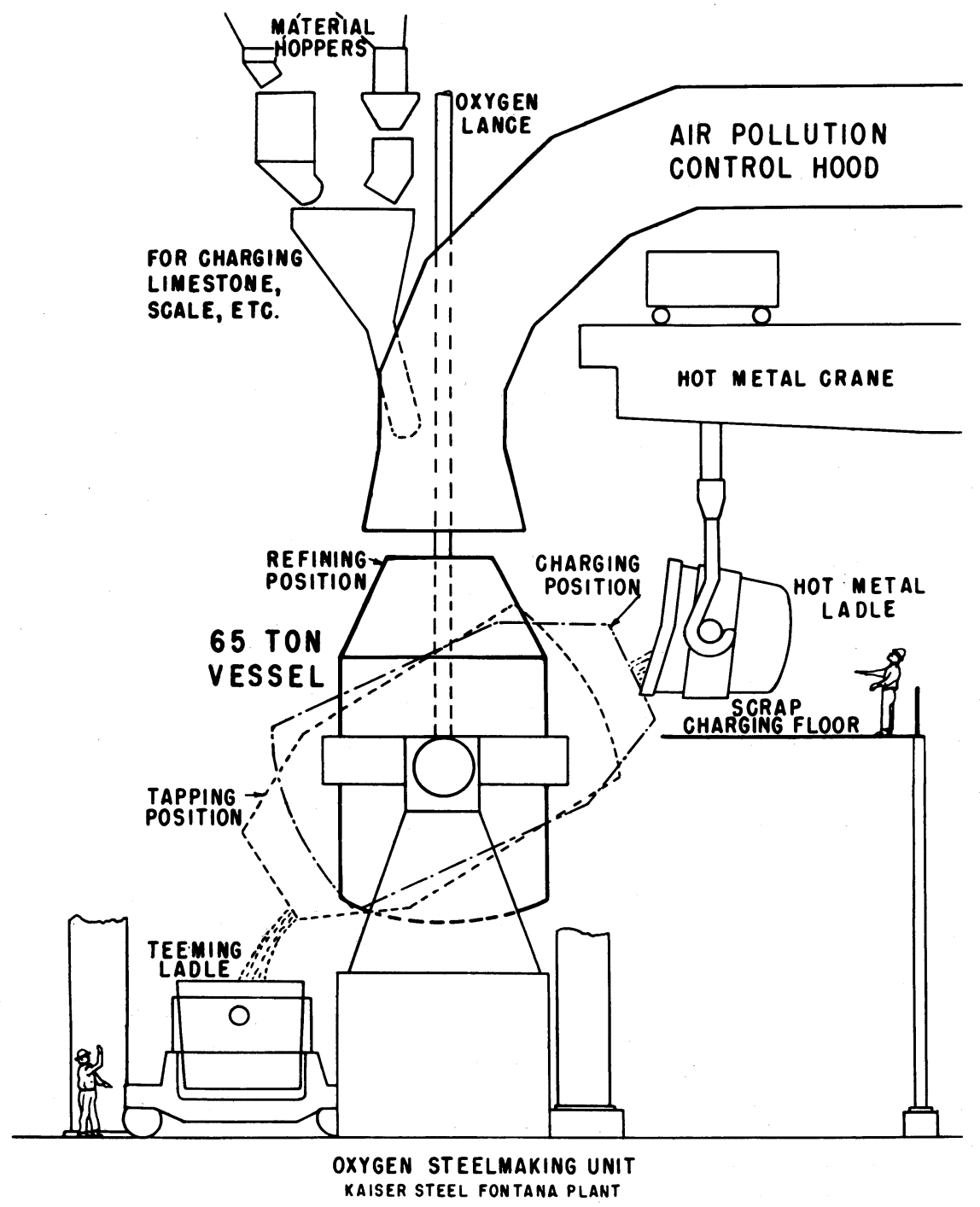

Produces: low carbon steel of low $\mathbf{N}$ and $\mathbf{O}$ content. Slag inclusions are few, and segregation is less.

Requires: low phosphorus pig iron and some 25 pct scrap in charge.

Advantages: bessemer production speed resulting in opệh hearth quality steel; moderate capital costs and low operating costs.

Disadvantages: speed of operation prevents catching carbon on way down; hence, without recarburization produces only low carbon steel. Process makes heavy volume of fumes. 